University of Louisville

ThinkIR: The University of Louisville's Institutional Repository

Electronic Theses and Dissertations

$12-2003$

\title{
Analyzing rhetoric : a frame analysis of the pro-life movement in the United States.
}

Juanita Raley Shever 1949-

University of Louisville

Follow this and additional works at: https://ir.library.louisville.edu/etd

\section{Recommended Citation}

Shever, Juanita Raley 1949-, "Analyzing rhetoric : a frame analysis of the pro-life movement in the United States." (2003). Electronic Theses and Dissertations. Paper 1319.

https://doi.org/10.18297/etd/1319

This Master's Thesis is brought to you for free and open access by ThinkIR: The University of Louisville's Institutional Repository. It has been accepted for inclusion in Electronic Theses and Dissertations by an authorized administrator of ThinkIR: The University of Louisville's Institutional Repository. This title appears here courtesy of the author, who has retained all other copyrights. For more information, please contact thinkir@louisville.edu. 
ANALYZING RHETORIC:

A FRAME ANALYSIS OF THE PRO-LIFE MOVEMENT IN THE UNITED STATES

$$
\text { By }
$$

Juanita Raley Shever

B.A., University of Louisville, 1996

\author{
A Thesis \\ Submitted to the Faculty of the \\ Graduate School of the University of Louisville \\ in Partial Fulfillment of the Requirements \\ for the Degree of
}

Master of Arts

Department of Sociology

University of Louisville

Louisville, Kentucky

December 2003 
ANALYZING RHETORIC:

A FRAME ANALYSIS OF THE PRO-LIFE MOVEMENT IN THE UNITED STATES

\author{
By \\ Juanita Raley Shever \\ B.A., University of Louisville, 1996
}

A Thesis Approved on

December 1, 2003

By the following Reading Committee:

Thesis Director 
Copyright $\odot 2003$ by Juanita Raley Shever

All rights reserved 


\section{DEDICATION}

This thesis is dedicated to

Dr. Lilialyce Akers

And

Dr. Morton Wenger 


\section{ACKNOWLEDGEMENTS}

I will be forever indebted to the faculty of the Sociology Department of the University of Louisville. Particularly, I would like to thank Dr. John Busch for agreeing to chair my thesis committee (even at this late date) and Dr. Susan Kelly for her invaluable contributions to the process. In addition, I would like to thank Dr. Jim Williams, Chair of the Department of Sociology and Social Work at Texas Woman's University, Denton, Texas, without whose encouragement and committee participation, I am certain, I would have never completed this project. In addition, I would like to acknowledge Dr. John Reiger, thanks to whom, I only had to take my Doctoral Methods Exam once. 


\section{ABSTRACT \\ ANALYZING RHETORIC: \\ A FRAME ANALYSIS OF THE PRO-LIFE MOVEMENT IN THE UNITED STATES

\author{
Juanita Raley Shever
}

December 1, 2003

The purpose of this study is to consider the significance of rhetoric used by prolife social movement organizations to frame the experience of abortion and to label those women who have participated in that experience. The study explores how frames are devised and how these frames are applied so that reality is organized in such a manner as to appear aligned with the religious, moral, and/or philosophical position of the pro-life movement. The study uses pro-life web pages to obtain data; then, analyzes the data for emerging themes and content. The general tasks of framing such as agenda setting are analyzed through the frames discovered in the data. These tasks and frames are constructed as a typology that shows the interactions between the tasks and the ideologies. 


\section{TABLE OF CONTENTS}

PAGE

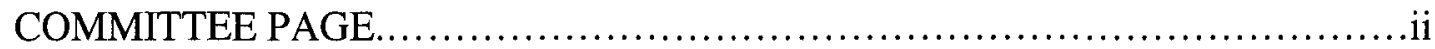

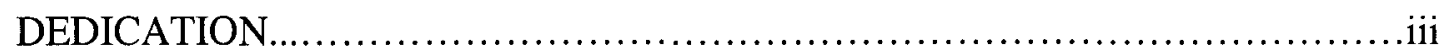

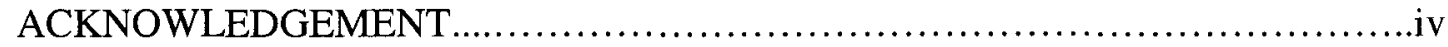

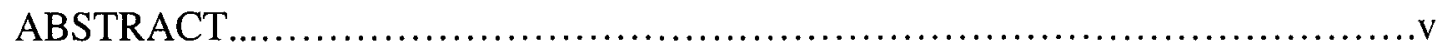

\section{CHAPTER}

I. INTRODUCTION

A. The Purpose of the Study ....................................

B. Problem Statement........................................

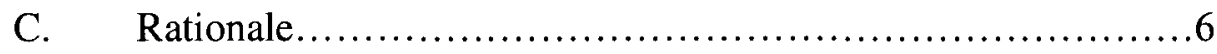

D. Significance of the Study....................................

II. REVIEW OF THE LITERATURE

A. General Literature ........................................... 9

B. Theoretical Literature.......................................14

III. THEORY AND METHODS

A. Research Problem........................................18

B. Research Questions......................................18

C. Definitions of Terms and Concepts.........................18

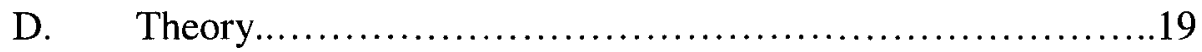

E. Data Collection and Methods...............................21

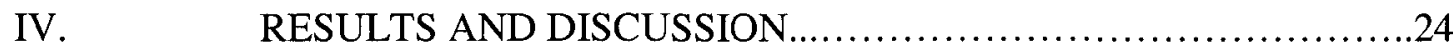


REFERENCES.

CURRICULUM VITAE. .43 


\section{CHAPTER I}

\section{INTRODUCTION}

\section{The Purpose of the Study}

The issue of women's rights to make autonomous decisions concerning their reproductive capabilities is an often-debated topic in legal, as well as socio-political circles; but women's rights to choose contraception and/or abortion are in no way presently guaranteed. Since 1980, when Joseph Scheidler and Paul and Judy Brown broke with Dr. Jack Wilke's National Right to Life Committee (NRLC), a well-organized and well-financed coalition of pro-life advocates, including elements of the religious right, conservative Republicans, and various pro-life social movement organizations, such as, Operation Rescue and Operation Save America, have come together to contravene the 1973 Roe v. Wade decision. The National Right to Life Committee was considered by these more radical pro-life activists "as a timid lobbying organization that was no longer effective towards their goal: the passage of a comprehensive "Human Life Amendment" to the Constitution that would outlaw all abortions" (Burghart 1996). The pro-life social movement envisioned by Scheidler, the Browns, and other radical pro-life advocates, such as Randall Terry, and his successor, Flip Benham of Operation Rescue, was planned as direct-action, grass-roots local organizations. However, at the national level the plan was for a hierarchically structured organization, which would decide movement. 
policy, distribute information, and enlist membership (Pro-Life Action League 2002).

Since the energy of the pro-choice movement, post Roe v. Wade, was focused primarily on implementing the rights set out by the decision, the pro-life groups "[took] matters into their own hands...to increase the opportunity costs faced by both abortion consumers and providers" (Kahane 2000: 466). This change in movement strategy from political lobbying to direct action required a change in the style of rhetoric used by this component of the pro-life movement. Recent research (Hopkins and Reicher 1997; Benford and Snow 2000) suggests that a more detailed understanding of the operations of social movements such as the pro-life movement may be gained by examining their uses of rhetoric in attracting and maintaining membership and motivating collective action.

The women's liberation movement of the 1960s used access to legal and safe abortions as a focal point of its political agenda. Although some states had already begun to liberalize their stances on reproductive rights, most states at that time still considered abortion to be unacceptable, legal or not, except in circumstances in which the mother's life, as defined by the medical profession, was in danger. When the Supreme Court decided that the U.S. Constitution assured women medical privacy, which encompassed abortion, pro-choice women were certain that access to abortion was legally established and would be protected. This has been tentatively the case since 1973; but if the coalition, established after the 1980 split in the NRLC, succeeds in re-framing the abortion question, not as a question of women's rights, but as a question of the fetus' personhood, as suggested by Kristin Luker (1984), the likelihood of abortion becoming illegal again will be greatly enhanced. 
The Roe v. Wade case was a constitutional challenge to the Texas 1854 statute against abortion [Roe vs. Wade, 410 U.S. (1973)], which had been for all intents and purposes unchanged from its inception until the Roe v. Wade decision was handed down in 1973. In the opinion of the court written by Justice Harry Blackmun, "the restrictive criminal abortion laws in effect in a majority of States... are of relatively recent vintage...[T]hey derive from statutory changes effected, for the most part, in the latter half of the $19^{\text {th }}$ century" (Roe vs. Wade, 410 U.S. 130-138); however, these relatively recent restrictive abortion laws are promoted by pro-life activists as the traditional view toward reproductive choices. Rhetoric is used to frame the pro-life position in a way "to both align the movement with the larger cultural dictates of society and to mobilize or maintain the support of members" (McCaffrey 2000: 42).

Although most early term abortion has been legal in the United States since the Roe decision, contrary to the pro-life activists' maxim of 'abortion on demand', abortion, as predicated on Roe, has always been restricted:

"(a) For the stage prior to approximately the end of the first trimester, the abortion decision and its effectuation must be left to the medical judgment of the pregnant woman's attending physician;

"(b) For the stage subsequent to approximately the end of the first trimester, the State, in promoting its interest in the health of the mother, may, if it chooses, regulate the abortion procedure in ways that are reasonably related to maternal health;

"(c) For the stage subsequent to viability, the State in promoting its interest in the potentiality of human life may, if it chooses, regulate, and even proscribe, abortion except where it is necessary, in appropriate medical judgment, for the preservation of the life or health of the mother [Roe v. Wade, 410 U.S. 113 (1973) 163-165].

Even with these legal stipulations in place, the conflict surrounding the issue of the availability of safe and legal abortions has yet to be resolved. 
The Supreme Court itself has contributed to the incremental dismantling of Roe v. Wade, by upholding individual state laws that limit the availability of abortion services to a greater degree than the spirit of the Roe decision anticipated. Through such decisions as those handed down in Webster v. Reproductive Health Services [492 U.S. 490 (1989) 88-605] and Planned Parenthood v. Casey [505 U.S. 833 (1992) 91-744], abortion availability has been restricted severely, particularly for poor and/or young women, by requiring counseling, waiting periods, parental permission or a judicial override for minors, and, in some cases, viability tests. These decisions seem to be judicial attempts "to reestablish policy-opinion congruence" (Mooney 2000: 172) by returning most abortion policy-making to the states. This is not to diminish the importance of the ongoing federal level pro-life efforts, e.g., the partial birth abortion ban to create a legal recognition of the fetus as a person, but to resolve the on-going abortion issue struggles. However, the outcomes, contrary to judicial expectations, seem to be as predicted by Prewitt and Blanchard in their study Religious Violence and Abortion (1993), "the activation of more pro-lifers and pro-choicers at the state and local levels...[and] an increasing kindling of extremism and violence" (14).

\section{Problem Statement}

This research analyzes the rhetoric utilized in the websites of the pro-life movement in the United States from 1995, the earliest available on-line data, through the present. This "Clash of Absolutes," as Laurence Tribe (1990) refers to the confrontation between the pro-life and pro-choice social movements, has been, in its modern incarnation, under way since the 1950s; but the perspectives proposed during the 1950s and 1960 s, the early period of this conflict, were limited by the legalistic and medicalized 
tone of the discourse. The early debate was primarily among three contending positions: the formal Roman Catholic position that abortion was murder and was never justified; the reform position that abortion should be legal in some cases; and the repeal position that abortion should be legal at the woman's request under any circumstance. These arguments, including the Catholic position, were framed in legal terminology, such as murder verses mother's rights, and the public (including both pro-choice and pro-life activists) accepted that the legality or criminality of receiving, providing, or securing abortion services would be decided within the purview of the legal and/or medical systems. Though the religious communities usually supported one or another of the three positions, even the Catholic community was not perfectly unified on one viewpoint (Tribe 1990).

In the positive response (Franklin and Kosaki 1989) perspective of the pro-choice movement, Roe v. Wade established the legality of the pro-choice position concerning abortion and that position would be protected, as are other legal decisions, by the full power of the state. Upon delivery of the Supreme Court decision in the Roe v. Wade case, pro-choice advocates set about the task of establishing abortion availability as a community presence, while generally ignoring the on-going organizational efforts of the pro-life social movement. This change in strategy, from advocate for abortion rights to facilitator of abortion services, on the part of the pro-choice movement, may have contributed substantially to the present decline in the availability of abortion services (Johnson and Martin 1998: 299).

In accordance with the tone of the discourse, the early strategy of the pro-life movement depended primarily on political lobbying, e.g., the National Right to Life 
Committee. However, when pro-life activists, such as Joseph Scheidler, Paul and Judy Brown, and Randall Terry, lowered the level of discourse from the political to the personal, it was necessary to reconstruct the rhetoric and reframe the issues to suit the strategies of the more radical pro-life social movement organizations. Since abortion was no longer considered only a political issue, using only a rational-legal frame, such as murder vs. mother's rights, would no longer suffice. Other frames would have to be constructed to resonate with different groups. Different rhetoric and rhetorical devices would be required to define those frames. This research identifies the rhetoric used by the pro-life social movement to frame abortion as a social problem, to motivate pro-life action, and to enlist and maintain group membership.

\section{$\underline{\text { Rationale }}$}

To date there have been only limited attempts to analyze the uses of rhetoric by social movements in general (Appelrouth 1999; Benford and Snow 2000) and the pro-life movement in particular (Hopkins and Reicher 1997). This research addresses this limitation in the literature on social movements and sheds greater light on the uses of rhetoric by the pro-life movement in the United States. This study uses Goffman's (1974) theory of frame analysis to analyze the manner in which the pro-life movement uses rhetoric to frame abortion as a social problem and the women who seek abortions as victims, to motivate pro-life action, and to enlist and maintain group membership. The time frame is limited to the period 1995 to the present, which is the time during which the pro-life movement has become highly visible on the Internet (Priests for Life 2001), has adopted a particular set of organizational and rhetorical strategies including efforts at heightened political and social visibility, membership recruitment (Pro-Life Action 
League 2002), and willingness to tolerate violent tactics (Blanchard and Prewitt 1993:

41).

\section{Significance of the Study}

When Roe v. Wade was decided, the standard argument concerning abortion was whether a woman had the right to make a private decision for herself about whether to carry a pregnancy to term. However, immediately after the decision was handed down, while the pro-choice groups were establishing clinics and facilitating the application of the law, the pro-life community was framing a different sort of argument. The reframed discourse became a debate not only over the "philosophical issue of personhood" of the fetus, as Kristin Luker hypothesized in Abortion and the Politics of Motherhood (1984), but also over what component of human life has more value, the biological or the social, the fetus or the adult woman. The pro-life social movement organizations became "Missionaries to the Unborn" (Missionaries to the Unborn 2003) and sometimes both judge and jury for doctors who performed abortions, employees of abortion clinics, and women who were seeking abortions (Horseley 2002). Scott Appelrouth (1999) observes that, "despite a group's initial discursive grounding, challengers targeting the state...find it necessary to frame their concerns within a "rational-legal" paradigm..." (329), able to be supported by evidence and/or precedence. A closer look at the rhetorical devices used to frame moral judgments concerning abortion into evidential arguments is a significant addition to the study of social movements and their operation. This analysis adds to the knowledge of the usefulness of rhetoric as a framing strategy generally and increases the information available on the usefulness of frame analysis to study "the organization of experience" (Goffman 1974: 13) within the pro-life movement. This research 
specifically analyses the rhetoric of the pro-life movement associated with the directaction plan of the radical pro-life factions. 


\section{CHAPTER II}

\section{$\underline{\text { Literature Review }}$}

Social movement research in the United States has described various aspects of the structure and operation of pro-life groups, such as the grassroots pro-life movement in Fargo, North Dakota (Ginsburg 1989) and the demonstrations in Milwaukee, Wisconsin (Shaw and Spinney 1999), but analysis of the impact of pro-life rhetoric has not been fully explored (Appelrouth 1999; Benford and Snow 2000). The issues primary to social movements are mobilization, attracting and holding adherents, and framing their perceptions of reality in a manner congruent with broader social norms. Social movement theory in the United States has been particularly limited in reference to rhetorical issues in the pro-life movement, especially the more radical groups such as Operation Rescue America (and its local divisions Operation Rescue West and Operation Rescue Boston) and the Pro-Life Action League (Hopkins and Reicher 1997:262).

The seminal work on abortion, from the socio-political perspective, is Abortion and the Politics of Motherhood (1984), in which Kristin Luker addresses three questions central to the abortion debate. First, that the "status of the embryo has always been ambiguous" (Luker 1984: 5) historically, socially, and philosophically; second, "the abortion debate is not about 'facts' but about how to weigh, measure, and assess facts" (Luker 1984: 5); and third, "the debate about abortion is a debate about personhood" (Luker 1984: 5). Luker's data was obtained from printed material, including newspapers, 
pamphlets, newsletters, and handouts, and from in-depth interviews with abortion activists, both pro-life and pro-choice. The report of her study was produced from content analysis of how abortion activists use language to defend a worldview or persuade through language that a particular worldview is moral and correct (Luker 1984). While Luker addresses primarily the social and philosophical side of the abortion question, Laurence H. Tribe (1990) addresses the legal history of the abortion controversy in his book, Abortion: The Clash of Absolutes. Luker and Tribe both attribute the illegalization of abortion in virtually all states by the early 1900 s to the American Medical Association's campaign to professionalize the medical community and gain control of the abortion practice (Luker 1984; Tribe 1990). Laurence Tribe also analyzes the demographic influences that encouraged the white, Protestant church to become involved in the debate. According to Tribe, much of the rhetoric used by the Family Values component of the modern pro-life movement is the same appeal to maintaining the male/female status quo, as was described in a report in 1871 published by the American Medical Association that "describes the woman seeking an abortion as 'unmindful of the course marked out for her by Providence' and characterizes her as selfish and immoral" (Tribe 1990: 33). Tribe further analyzes the legal attempts by the pro-life movement to undermine the Roe v. Wade decision from the legislative restrictions on abortion including parental or husband's consent through waiting periods to restrictions on the types of procedures that abortion clinics are allowed to perform (Tribe 1990). Tribe concludes that the restriction of abortion is in fact a restriction on the freedom of women to choose their own life's path and that with the undermining of this legally mandated right, other rights may also be restricted, for all people, both born and 
unborn (Tribe 1990).

Faye Ginsburg reports in Contested Lives (1989) that both pro-choice and pro-life activists in Fargo, North Dakota felt that they were defending their place as women. The pro-life activists referred to abortion as "a decline in the culture and the rape of motherhood" (Ginsburg 1989: 99) upholding the perception of female as giving birth, being pregnant, but equating abortion with the male action of rape. This frame of the experience of abortion goes so far as to strip the woman having an abortion of her femaleness. The pro-life movement frames her as having refused her traditionally assigned role of nurturer by demanding autonomy in her reproductive decisions. The focus of Ginsburg's study, grass-roots activism, in one limited area, Fargo, North Dakota, gives a different view of pro-life rhetoric and activism. The rhetoric used by these prolife women was basically the same as that used by the larger movement, but more personal and more woman-oriented than the more broadly conceptualized rhetoric of the national organizations. When the pro-life and pro-choice women came together to participate in a dialogue, it seemed that other than that one issue, abortion, they had more in common than they thought (Ginsburg 1989). "[E]ach group desire[d], in its own way, to alleviate the unequal conditions faced by women in American culture" (Ginsburg 1989: 226).

In Decoding Abortion Rhetoric: Communicating Social Change (1990), Celeste Condit addresses the rhetoric of both pro-choice and pro-life activists from the $1960 \mathrm{~s}$ early debate through 1985 . She points out that while women have the right to choose abortion, the rhetoric employed by the pro-life movement has compromised that right by promoting choice as "an undesirable moral act... legally permitted but not publicly 
financed" (199). She further points out that this lack of public financing brings in the issues of race and class as defining factors in who is allowed to choose abortion. Condit explains that public discourse is composed of rhetoric, defined in the classical sense of persuasion through argumentation, and other devices, such as the posters of aborted fetuses and the "little feet" pin. Condit traces the progression of abortion discourse from the legal forum of the 1970s through the mass culture persuasion techniques of television. She concludes that social change might be best understood by analyzing the public discourse and rhetoric that surround the debate.

In his article Moral Reform and the Anti-Abortion Movement (1987), Alan Clarke describes the anti-abortion movement in the United Kingdom as a moral crusade, which "can be seen to possess well formulated protest ideologies. These provide frameworks for action and consist of values, norms and ideals which protestors wish to see widely promoted and publicly endorsed" (125). Clarke analyzes rhetoric through campaign literature of the Society for the Protection of the Unborn Child and the LIFE organization of the United Kingdom as it frames both women and fetuses as victims of abortion; women as victims of unscrupulous abortionists and pressuring families and boyfriends; fetuses as victims of promiscuous and selfish women; and both women and fetuses as victims of conniving males who simply want to be rid of the responsibility that comes along with fatherhood. Clarke defines two totally opposed methods by which pro-life activists respond to the abortion patient, provider, or procurer, either the assimilative, the defensive, method or the coercive, the aggressive, method. Which method is used in which situation is decided by how the offender or enemy is defined. If the offender is repentant, the victim frame, the assimilative method is acceptable; but if the offender is 
non-repentant, will not be framed as a victim or offender, the coercive method is applied. Clarke defines the pro-life movement in the UK as "a movement of cultural fundamentalism...in both its aggressive and defensive forms" (1987: 144). He concludes that while the pro-life movement is both a cultural and political protest, in order to understand the movement, it must be framed in the broader concept of moral reform. Another of the various frames discovered through analyzing rhetoric is the framing of abortion as detrimental to women's health. This aspect was investigated by Nick Hopkins, Steve Reicher, and Jannat Saleem in their paper, Constructing Women's Psychological Health in Anti-Abortion Rhetoric (1996). Hopkins, Reicher, and Saleem view framing as "an important moment in the process of political mobilization...Such framing not only determines whether situations are experienced as tolerable or not, but set important parameters on the nature of any collective action" (Elder and Cobb, 1983; Edelman, 1977; Schneider, 1985; Best, 1987; Snow, Rochford, Worden and Benford, 1986; Lee and Ungar, 1989; Williams, 1995; cited in Hopkins, Reicher, and Saleem 2001). Hopkins, Reicher and Saleem address the rhetoric and discourse surrounding the alleged psychological condition referred to by pro-life activists as Post-Abortion Syndrome (PAS). "PAS is defined as referring to the delayed development of symptoms resulting from the physical and emotional trauma of abortion and is construed as a type of 'Post Traumatic Stress Disorder' (PTSD) akin to that perceived in war veterans" (Hopkins et al. 1996: 544). They address other pro-life discourses, such as the baby/fetus rhetoric and the PAS/denial construction. According to the analysis of Hopkins, et al. (1996), the construction of abortion as detrimental to women's health may be an important strategy for the pro-life movement. If this rhetoric is developed, it may allow 
the pro-life movement to claim to be acting in the interests of women's health and to downplay the privileging of a particular worldview, as in the baby/fetus rhetoric. "The distance between the psychological discourse of PAS and the more overtly political/moral discourses of traditional anti-abortion argumentation, may give the former considerable potential to structure people's understanding of who has what at stake in the abortion debate" (Hopkins, Reicher, and Saleem 1996: 561).

The ultimate proposition in the post-Roe general debate has over time shifted from the legal argument against murdering the fetus to the question of competing rights, those of the mother and those of the fetus. Even the photographic attacks against abortion made by pro-life factions depend on framing the photographs of aborted fetuses in such a way as to accentuate their resemblance to newborn babies, e.g., the "little feet" pin. This is a pin that is very popular with pro-life groups, which is copied from a poster depicting the feet of a ten-week-old fetus held between the fingers of an adult man. While a ten-week-old fetus is very unlike a newborn baby in appearance otherwise, the feet are quite similar. In order to cover the other discrepancies in appearance and to insinuate that the fetus is a baby, the body of the fetus is hid behind the man's fingers (Hopkins and Reicher 1997:268). But according to Hopkins, Reicher, and Saleem, the next most important advance for pro-life activists may be the construction of abortion as against the health interests of women (Hopkins, Reicher, and Saleem 1996).

\section{Theoretical Literature}

In approximately the last twenty years sociologists have begun employing alternate theories such as frame analysis to study the rhetoric of social movement activists (Soloman 1980; Staggenborg 1991). These analyses have been used in social 
psychological studies, such as Hopkins and Reicher's Social Movement Rhetoric and the Social Psychology of Collective Action: A Case Study of Anti-Abortion Mobilization (1997), which analyzes the pro-life movement in the United Kingdom, using SelfCategorization Theory as a means of explaining how pro-life groups attract members. This study analyzed a speech, presented to a group of prospective new members, who in this case were "an audience of medical students/staff at a teaching hospital...addressed as members of the medical profession with the speaker constructing a contradiction between this identity and abortion" (Hopkins and Reicher 1997:267). The rhetoric of the speech created "category boundaries and category contents which represented their (pro-lifers) own position as embodying the mass of public opinion and their opponents (pro-choicers) as isolated and peripheral figures" (Hopkins and Reicher 1997:267). The rhetorical construction of fetal personhood was central to the pro-life presentation and "represents the anti-abortion construction of the fetus as firmly grounded in, and indeed as arising from, the common-sense knowledge and everyday experiences of a category of people whose boundaries are so widely set as to include all 'ordinary'/ 'everyday' people" (Hopkins and Reicher 1997:281). Another point made in the study was the absence of women as autonomous agents. The presentation compared women's wombs to test tubes and incubators, constructing women rhetorically as the "particular environment...a nonanimate container" (Hopkins and Reicher 1997:279) that the fetus requires to exist. In conclusion, the importance of analyzing rhetoric for "the work that it does in constructing social category definitions" (Hopkins and Reicher 1997:283) is emphasized.

Frame analysis has also been used in studying the women's movement from the perspective of media framing where Terkildsen and Schnell, How Media Frames Move 
Public Opinion: An Analysis of the Women's Movement (1997), "ascertain five unique frames from the 1950s through the 1990s: a sex roles frame, a feminism frame, political rights frame, economic rights frame, and anti-feminism frame" (879). "Using a content analysis of weekly print coverage from 1950 to 1995 " (880), Terkildsen and Schnell document the multiple media frames constructed to define the women's movement. Another component of the research was to "evaluate the impact such organizational devices had on public opinion by approximating the extent to which frames influenced public opinion toward the women's movement, feminists and related policy issues" (880). Terkildsen and Schnell concluded that their findings supported the hypothesis "that media frames not only alter issue conceptualization, but also produce a net shift in citizens' issue support" (885).

The study of the Christian Coalition of New York by Scott Appelrouth, Shifting Frames and Rhetorics: A Case Study of the Christian Coalition of New York (1999), is of particular interest in the context of this study since his focus was on both rhetoric and frame analysis. This study addressed "the dynamics of rhetorical frames and how they are utilized by leaders of a social movement organization" (Appelrouth 1999:329). The study was particularly interesting in its plan to study the processes of frame construction and rhetorical dynamics of the Christian Coalition in reference to "an avowedly public institution...supported through public funds (335)," a city's board of education. Appelrouth (1999) concludes that moral argument is often seen as being of a "secondary status" (336) and that as the United States turns "ever more frequently to the legal system to resolve moral and normative conflicts, organizations which choose to confront moral issues through the legal system, must be ready to reframe their issues through the 
"strategic use of rational-legal discourse and its power to define 'reality' " (Appelrouth 1999:337).

An examination of this literature indicates that in the words of Benford and Snow (2000: 611), "[f]raming processes have come to be regarded, alongside resource mobilization and political opportunity processes, as a central dynamic in understanding the character and course of social movements" (Benford and Snow 2000:611). This study concerning the rhetoric and framing processes particular to the direct action pro-life organizations, such as Operation Rescue America and the Pro-Life Action League, adds to the store of knowledge concerning how and why social movements such as these operate. 
CHAPTER III

THEORY, DATA, AND METHODS

$\underline{\text { Research Problem }}$

This study analyzes how the pro-life social movement has used rhetoric and rhetorical devices to frame the abortion debate in such a manner as to best accommodate the pro-life position.

\section{$\underline{\text { Research Questions }}$}

This study examines the following questions:

1. What is the primary role of rhetoric in pro-life organizations?

2. What rhetoric is employed by the pro-life movement to "frame" abortion as a social problem?

3. How do pro-life social movement groups enlist group members?

4. How have pro-life organizations used rhetoric to create collective mobilization?

\section{Definition of Terms and Concepts}

The following terms are used in this study:

- Frame Analysis - Sociologist Erving Goffman theorized "that definitions of a situation are built up in accordance with principles of organization which govern events - at least social ones - and our subjective involvement in them..." (Goffman 1974:10-11). His term referring to the elements of this process, which we are able to identify, is to "frame" and "frame analysis" (Goffman 1974:10-11) is his method of examining those experiences through analysis of the language used to describe them. 
- Frame Construction - A "processual phenomenon that implies agency and contention at the level of reality construction. It is active in the sense that something is being done, and processual in the sense of a dynamic, evolving process" (Benford and Snow 2000:614).

- Core Framing Tasks - Benford and Snow (2000) identify three framing tasks in the frame construction process:

1. Diagnostic Framing - problem identification and attributions

2. Prognostic Framing - the articulation of a proposed solution to the problem

3. Motivational Framing - provides a rationale for engaging in collective action, including construction of a vocabulary of motive (615-617)

- Vocabularies of Motive - Kenneth Burke and C. Wright Mills saw "motives as rhetorical constructs that impose meaning onto social interaction. Motives are not inner springs of action...but normative vocabularies by which actors define situations" (Hopper 1991: 1).

\section{Theory}

The basic theory behind this study is Erving Goffman's concept of framing (1974). Goffman defined frames as "schemata of interpretation" that enable individuals "to locate, perceive, identify, and label" (Goffman 1974: 21; cited in Benford and Snow 2000: 614) and organize experiences into a construction of reality. This theoretical perspective is used in categorizing the data into frames particular to the individual social movement organizations. 
This study of pro-life social movement rhetoric is a study of the ability of the radical segments of the movement to negotiate meaning that will within a contextual framework resonate with a broad constituency. Different social movement organizations use different rhetoric to create similar outcomes among their particular groups of interest, such as health concerns among medical students and family value issues at a Promise Keeper convention.

The second theoretical position used is that of Robert Benford and David Snow. This perspective is a bit more social constructionist than Goffman's organizational perspective. Benford and Snow contend that framing is "an active, processual phenomenon that implies agency and contention at the level of reality construction" (2000: 614). The outcomes of the framing process, according to Benford and Snow, are collective action frames that "are not merely aggregations of individual attitudes and perceptions but also the outcome of negotiating shared meaning" (Gamson 1992a: 111; cited in Benford and Snow 2000). From the social constructionist perspective, as rhetoric is purveyed as cultural fact and becomes incorporated into the social movement ideology, the "constructing or reconstituting meaning" (Berbrier 1998: 433) is complete. If the framing effort is successful, the frames will have been constructed in such a manner as to resonate with the "targets of mobilization" (Berbrier 1998:433); if not, frame transformation can be employed "by reconstituting the meaning of what is going on for participants, developing alternative frames that might better align with conventional (and hence authoritative) interpretive frames" (Berbrier 1998: 433; Snow et al. 1986: 473474). 


\section{$\underline{\text { Data Collection and Methods }}$}

Data

Data were drawn from websites profiled on the Alternative Pro-Life Links (http://www.mttu.com/links.htm) page sponsored by the Missionaries to the Unborn (http://www.mttu.com/main.htm) and General Pro-Life Sites from the Pro-Life Action Network page (http://www.prolifeaction.org/links.htm). These pages were chosen on the basis of visibility and availability of data. The data cover the period 1995 to the present.

Every fifth website listed was chosen to be included in the analysis. If a website was listed on both links pages, the repeat listing was excluded and the sixth listing was used. If the fifth website was not appropriate to analysis, such as the website March for Life - http://www.marchforlife.org - which is an organizational website for the annual pro-life march in Washington, D.C., that site was excluded and the sixth listing was used. Each chosen website included information that was relevant to the research questions, i.e., recruitment, mobilization, mission statements, and beliefs. The number of websites included was limited to fifteen.

The websites included in the analysis are as follows:

- The Center for Bio-Ethical Reform - http://www.abortionno.com/

- National Right to Life - http://www.nrlc.org/

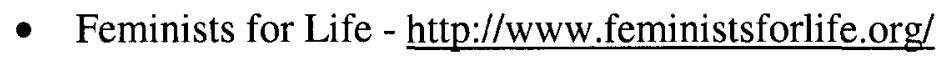

- Survivors - http://www.survivors.la/

- Life Research Institute - http://www.geocities.com/kekogut/

- Rachel's Page - http://www.geocities.com/Heartland/Plains/2845/

- Full Quiver Ministry - http://www.fullquivermission.com/ 
- Missionaries to the Pre-Born - http://www.missionariestopreborn.com/

- Rock for Life - http://www.rockforlife.org/

- Life and Liberty Ministries - http://www.lifeandlibertyministries.com/

- Rightgrrrl - http://www.rightgrrl.com/

- LifeDynamics.com - http://www.ldi.org/

- Operation Save American - http://www.operationsaveamerica.org/

- Pro-Life Action League - http://www.prolifeaction.org/

- Operation Rescue - http://www.operationrescue.org/

While the number of websites chosen was limited to fifteen, this included five sites that were chosen because they were of particular interest. These sites are Operation Save American, Pro-Life Action League, Operation Rescue, LifeDynamics.com., and Rightgrrrl. These sites did not fit into the scheme used to choose the first ten sites. They were chosen because of my personal interest in the organization, such as Life Dynamics. I viewed a demonstration held by Life Dynamics that included the posters of aborted fetuses and due to this experience, I was interested in that site and the rhetoric therein particularly. Others were chosen because of their particular position in the history or ideology of the movement, such as Rightgrrrl. This site uses particular types of rhetorical devices, such as the use of "grrrl," through which the organizations is intending to attract the young, empowered woman, but with the prefix "Right" limiting the group to conservative women. The last three sites, the Pro-Life Action League, Operation Rescue, and Operation Save America were chosen because of their history in the movement. They were among the first of the pro-life social movement organizations to employ the rhetorical strategies being investigated. These sites are the last five listed above. 


\section{Data Collection}

Relevant web pages, such as mission statements, contact pages, on-line articles, and statements of ideologies, were printed for evaluation. On each of the websites there were links to pages included in the site. I chose each of those links, printed the page(s), returned to the homepage and chose another link, printed the page(s), and so forth. This same procedure was followed through each of the selected websites. After the pages were printed, I checked each page to decide whether the page was appropriate to the research. Pages, such as pleas for money, blank pages, and pages for emailing the organization were discarded, leaving 217 pages of useable data.

\section{Data Analysis}

Data were analyzed for recurrent and/or emergent rhetorical themes, such as fetal personhood, abortion as genocide, abortion related breast cancer. Key words and phrases, such as unborn child, disability cleansing, PAS, breast cancer, victims, were color coded and the data were sorted according to the primary theme of the page; then, the data were categorized by the research question that it addressed, such as, framing abortion as a social problem, motivating pro-life action, or enlisting group members. The analytic strategy relied on the construction of a typology, described by Lofland and Lofland (1995: 126) as a "process of charting the possibilities that result from the conjunction of two or more variables." The following set of typologies illustrates the rhetorical themes and styles relating to the issues of framing abortion as a social problem, motivating pro-life action, and/or enlisting group membership.

After analyzing the data for recurrent themes, phrases, and keywords, such as fetal rights, abortion related health issues, genocide, I sorted the data according to those 
subjects. I, then, as sole arbiter, determined the categories and assigned to these categories and themes labels that I considered appropriate.

\section{Figure 1: Typology of Pro-Life Rhetoric}

Web Pages:
The Center for Bio-Ethical Reform; Life
Dynamics; Survivors; Operation Rescue;
Operation Save America
Key Words and Phrases:
Genocide, Victim Class, Holocaust,
Lynchings, Deny the Personhood of the
Unborn
Theme(s): Political; Social; Religious;
Medical
Subject:
Genocide

\section{Web Pages:}

Dynamics; Survivors; Operation Rescue; Operation Save America

\section{Key Words and Phrases:}

Genocide, Victim Class, Holocaust, Lynchings, Deny the Personhood of the

Theme(s): Political; Social; Religious; Genocide

\section{Web Pages:}

Full Quiver Ministry; Missionaries to the Preborn; Life and Liberty Ministries; Rachel's Page; Pro-Life Action League; Operation Rescue

Key Words and Phrases:

Breadwinner; Traditional Marriage; Defense of Marriage Act; Motherhood

Theme(s): Religious; Political; Social

\section{Subject:}

Family Values

Web Pages:

National Right to Life; Feminists for Life; Life Research Institute

Key Words and Phrases:

Breast Cancer; Post-Abortion Syndrome (PAS); Abortion-Breast Cancer Link; ABC Link; Female Genital Mutilation

Theme(s): Medical; Political; Social

Subject:

Health and Medical Issues

Web Pages:

Pro-Life Action League; Operation Rescue; Operation Save America; Feminists for Life

\section{Key Words and Phrases:}

Legal Protection for the Unborn; The Unborn Victim of Violence Act; Unborn Child/Baby; Fetal Homicide;

Theme(s): Religious; Medical; Political; Social

Subject:

Rights Woman/Fetus

\section{Web Pages:}

Feminists for Life; Life Research Institute; Rightgrrrl

\section{Key Words and Phrases:}

Refuse to Choose; Women Deserve Better; Anti-Woman; Pro-Life Feminists; Abortion Violence; Pro-Abortion

Theme(s): Religious; Medical; Political; Social

\section{Subject:}

Woman's Issues 


\section{Limitations}

Data are not comprehensive, which limits the scope of the research. Conclusions are not generalizable to rhetoric used by all social movements, since the sample was very small. Even though the scope of the study is limited, the conclusions have shed some light on the understanding of rhetoric as an organizing strategy and on the usefulness of frame analysis to study "the organization of experience" (Goffman 1974: 13) within the pro-life movement. 


\section{CHAPTER IV}

\section{RESULTS AND DISCUSSION}

The first question addressed in these findings is the general role of rhetoric in prolife organizational discourse. Rhetoric is the use of words to persuade and, in this social constructionist application, to frame the pro-life perspective of the abortion issue in a manner that is broad enough to reach both radical and moderate pro-lifers alike. Although different pages focus on the construction of different frames, there was considerable overlap in the rhetorical themes used to support these positions.

As Cress and Snow (2000) pointed out, there are three primary tasks in the framing process that must be addressed if movement goals are to be attained. These "core framing tasks" (Benford and Snow 2000: 615) include diagnostic framing which "problematizes and focuses attention on an issue, helps shape how the issue is perceived, and identifies who or what is culpable, thereby identifying the targets or sources of the outcomes sought; prognostic framing (which) stipulates specific remedies or goals for the social movement organization to work toward and the means or tactics for achieving these objectives" (Cress and Snow 2000: 1071); and finally, if the previous tasks are well-negotiated, a positive outcome, either enlisting new membership or movement collective mobilization, is expected to take place.

As the following tables illustrate, there were five frames identified in the rhetoric used in the web pages analyzed. I have labeled these frames as Pro-Woman, 
Genocide/Holocaust, Family Values, Rights- Woman/Fetus, and Women's Health. Table

1 addresses Research Question 1 - what is the primary role of rhetoric in pro-life

organizations? The table sums up the use of rhetoric in completing the primary tasks

necessary in frame construction and how each of the five frames is defined.

Table 1: Rhetoric and Core Framing Tasks

\begin{tabular}{cccccc}
\hline $\begin{array}{c}\text { Core- } \\
\text { Framing } \\
\text { Tasks }\end{array}$ & $\begin{array}{c}\text { Family } \\
\text { Values }\end{array}$ & $\begin{array}{c}\text { Women's } \\
\text { Health }\end{array}$ & $\begin{array}{c}\text { Genocide- } \\
\text { Holocaust }\end{array}$ & $\begin{array}{c}\text { Pro- } \\
\text { Woman }\end{array}$ & $\begin{array}{c}\text { Rights } \\
\text { Woman/Fetus }\end{array}$ \\
\hline $\begin{array}{c}\text { Diagnostic } \\
\text { Task }\end{array}$ & $\begin{array}{c}\text { Decline of } \\
\text { Traditional } \\
\text { Family }\end{array}$ & $\begin{array}{c}\text { Physical and } \\
\text { psychological } \\
\text { consequences }\end{array}$ & $\begin{array}{c}\text { Social } \\
\text { Consequences/ } \\
\text { Holocaust }\end{array}$ & $\begin{array}{c}\text { Exploitation/ } \\
\text { Abortionists, } \\
\text { Families, etc }\end{array}$ & $\begin{array}{c}\text { Unborn Child/ } \\
\text { Incubator } \\
\text { Woman }\end{array}$ \\
$\begin{array}{c}\text { Prognostic } \\
\text { Task }\end{array}$ & Patriarchy & $\begin{array}{c}\text { Eliminate all } \\
\text { abortion }\end{array}$ & $\begin{array}{c}\text { Eliminate all } \\
\text { abortion }\end{array}$ & $\begin{array}{c}\text { Protect } \\
\text { Pregnancy }\end{array}$ & $\begin{array}{c}\text { Self Precedes } \\
\text { Society }\end{array}$ \\
$\begin{array}{c}\text { Motivational } \\
\text { Task }\end{array}$ & $\begin{array}{c}\text { Religious/ } \\
\text { Social }\end{array}$ & $\begin{array}{c}\text { Medical/ } \\
\text { Social }\end{array}$ & $\begin{array}{c}\text { Political } \\
\text { Social }\end{array}$ & $\begin{array}{c}\text { Political/ } \\
\text { Social }\end{array}$ & $\begin{array}{c}\text { Social/ } \\
\text { Political }\end{array}$ \\
\hline
\end{tabular}

The primary role of rhetoric in pro-life organizations is to create and develop frames that resonate with the world-view or general beliefs of targeted constituencies. The general frames above are constructed to reflect the ideals of audiences, which although they are all pro-life, may have political, religious, or social differences that demand a different spin on the standard rhetoric, such as the rhetoric employed in constructing the Rightgrrl - Rights Woman/Fetus frame and that of the Pro-Life Action

\footnotetext{
${ }^{1}$ Including Post Abortion Syndrome (PAS) which is not officially recognized by the psychiatric community as an actual malady, but is put forth by the Pro-Life movement as a psychological reaction to the abortion experience comparable to Post Traumatic Stress Disorder (PTSD) experienced by Viet Nam veterans and a statistically significant correlation between breast cancer and abortion which is contested among medical studies. (http://www.rightgrrl.com/pas.html).

${ }^{2}$ Comparing the decision to terminate a pregnancy to the Jewish Holocaust during WWII. Focuses primarily on the abortion of fetuses with probable disabilities http://www.actrtla.org.au/abortion/unborn.htm
} 
League - Family Values frame. The Rightgrrl web-page states "we don't believe the rights of the unborn should be subordinated to the rights of women, simply because we've been historically denied the vote" (Rightgrrl 1997-2002). This page constructs the argument for fetal rights using a political, rights-oriented rhetoric; while the Pro-Life Action Leagues constructs the same rhetorical argument, but bases the discourse on a religious theme, i.e., "[t]he truth is that abortion kills innocent human beings, made in the image and likeness of Almighty God" (Pro-Life Action League 2002). Although each of the organizations is constructing the argument that unborn fetuses have rights that must supercede those of adult women, they use different rhetorical themes in support.

The Family Values Frame diagnoses the abortion problem as resulting from a perceived decline in the traditional organization of the family based on religious values. The answer to this problem is a return to the traditionally organized family with the male breadwinner and the female homemaker, who, even if she works outside the home, is responsible for most aspects of child-rearing, the moral and spiritual condition of the family, and the general care-giving tasks within the family unit. This construction is illustrated in The Full Quiver Ministry web-site that states their purpose as teaching "God's will concerning His plan for families to Christians who have taken the world's view of Birth Control and insist on preventing the Blessings and Rewards that God would otherwise give them" (Full Quiver Ministries 2003). On this same page, Martin Luther is quoted as saying "the purpose of marriage is not to have pleasure and to be idle but to procreate and bring up children, to support a household. Those who have no love for children are swine, stocks, and logs unworthy of being called men or women; for they despise the blessings of God, the Creator and Author of marriage" (Full Quiver Ministries 
2003). This pro-life page proposes that not only abortion be banned, but contraception, tubal ligation, and vasectomies, as well.

The Women's Health Frame diagnoses the problem with having an abortion as being detrimental to the health of women. The prognostic frame supports elimination of all abortion, believing that the alleged consequences, the possibility of Post Abortion Syndrome (PAS) and/or breast cancer, should preclude the decision to have an abortion. Both medical and social rhetoric are used to construct the motivational frame. The alleged medical consequences of choosing abortion are purported to outweigh the social consequences of an unwanted pregnancy. A link from the Life Dynamics web-site states, "[m]edical experts have universally recognized since 1970 that the earlier a woman has her first full term pregnancy (FFTP), the lower her risk for breast cancer is. Anti-cancer groups tell women that late FFTP (30 years of age or older) increases risk, but this is a half-truth. Each year that a woman delays her FFTP, her risk climbs markedly" (Coalition on Abortion/Breast Cancer 2003). On that same page these statistics were cited, "breast cancer rates in the developed nations could be reduced by more than one-half if only women would bear more children and breastfeed for longer duration [Beral, V (July 20, 2002) Lancet 360:187-95]" (cited on Coalition on Abortion/Breast Cancer 2003).

The Genocide-Radical Frame diagnoses the abortion problem by comparing aborted fetuses to the Jewish Holocaust of Nazi Germany, claiming for and applying to the fetus, the notion of a socialized self who has individual social position, rights, and obligations. The prognostic frame for this position is the elimination of all legal abortion through political and social mobilization. Although, many web-sites equate abortion with genocide, the Center for Bio-Ethical Reform site makes the most adamant statements 
comparing abortion to "Jewish Holocaust victims, African Americans killed in racist lynchings, Native Americans exterminated by the US Army, etc." Their stated purpose "is to illuminate the conceptual similarities which exist between abortion and more widely recognized forms of genocide. This is important because perpetrators of genocide always call it something else..." (Center for Bio-Ethical Reform 2003). Their means of getting the message out is a "traveling photo-mural exhibit that compares the contemporary genocide of abortion to historically recognized forms of genocide" (Center for Bio-Ethical Reform 2003).

The Pro-Woman Frame diagnoses the abortion problem as due to the exploitation of women by abortionists and others, such as boyfriends or parents. The prognostic frame for this position is to protect the pregnancy whether that is the woman's choice or not. The Feminists for Life web-page claims that "[g]roups like Feminists for Life and pregnancy resource centers regularly get calls from women who are pressured by partners who say they will pay $\$ 300$ for an abortion but won't pay a dime in child support. Men and boys need to know that, thanks to legislation supported by Feminists for Life and other women's organizations that strengthens child support enforcement and paternity establishment, they can no longer coerce women into having an abortion by threatening to abandon their children if they are born" (Feminists for Life 2000).

Finally, the Rights-Woman/Fetus Frame diagnoses the abortion problem as a question of whether a woman has the right to decide whether to carry a pregnancy to term or does the fetus have a right to a future life that supercedes the rights of the woman. This is not just a question of when does a fetus become a person, but a question, also, of what component of human life has more value, the biological or the social, the fetus or 
the adult woman. As the pro-life movement argues for the rights of the unborn, it presumes that self, an outcome of the socialization process, is inherent to the fetus, that self precedes society. While the motivational rhetoric for each general frame involves religious, medical, and/or political aspects, a social component is also necessary to round out the framing to generate a basis for collective mobilization.

Table 2 addresses Research Question 2 - what rhetoric is employed by the pro-life movement to "frame" abortion as a social problem? The table sums up the themes uncovered and to what extent, measured in counted pages (number of pages out of the 217 pages analyzed that contained some or all of the keywords or phrases that indicate a particular subject) and percentages (total number of pages in that theme divided by the total number of pages in that frame), each frame depends on particular themes to support the position. The Family Values Frame was supported on all pages by a religious theme. On some pages a political or social theme was used to enhance the power of the rhetoric. According to Operation Save America, "there are no cheap political solutions to the holocaust presently ravaging our nation. Like slavery before it, abortion is preeminently a Gospel issue. The Cross of Christ is the only solution" (Operation Save America 2003), but according to the National Right to Life web-page supporting the traditional organization of the family, "as long as women give into the expectation that they ought to kill their children in order to get further in this world (that is, compete equally with men [emphasis added]), they really are "second-class" citizens" (National Right to Life 2003). The one component that was not employed in the Family Values Frame was the medical theme. The Women's Health Frame was supported on all pages by a medical theme. On some pages a political or social theme was also used. "According to medical studies, an 
American woman, on average, has a $12 \%$ chance of contracting breast cancer over the course of her lifetime. But that average risk increases by half - - to $18 \%$ - - for women who have had at least one induced abortion. That "average" hides a grim reality: in particular categories of women the chances of having breast cancer are very much higher should they choose to abort" (National Right to Life Commission 2001). The NRLC further states, "the determined effort of the pro-abortion lobby to cover up the harmful long-term effects of abortion on women and lie about them is truly cruel. It leaves women unprotected and vulnerable to health risks" (NRLC 2001). These claims are staple rhetoric in the radical pro-life social movement, even though the findings have been questioned by mainstream physicians and researchers. The component that was not employed in the Women's Health Frame was the religious theme.

The Genocide/Holocaust Frame and the Rights - Woman/Fetus Frame were both primarily supported by the political component. According to the Life Dynamics (2003) web-page, "[t]oday, abortion is justified by claiming the killing of babies is "safe and legal." Dr. Michael Jackson, an abortionist and clinic owner said, "I just go by what the courts say. I only do what's legal." These were the same justifications used by doctors who participated in the massacre of millions at Auschwitz. Zyklon-B, the poison gas used to kill the Jews, was seen as helping to alleviate suffering and permit humane killing." The Center for Bio-Ethical Reform has constructed a Genocide Awareness Project, which "exhibits large photo murals comparing aborted babies with Jewish Holocaust victims, African Americans killed in racist lynchings, Native Americans exterminated by the US Army, etc." The stated purpose "is to illuminate the conceptual similarities which exist between abortion and more widely recognized forms of genocide 
Table 2. Rhetorical Themes Present in Frames ${ }^{\text {a }}$

(Percentage in Each Cell is the Percent of Web Pages in that Cell of the Total Pages for that Cell's Rhetorical Theme)

\begin{tabular}{cccccc}
\hline \multirow{2}{*}{$\begin{array}{c}\text { Rhetorical } \\
\text { Themes }\end{array}$} & $\begin{array}{c}\text { Family } \\
\text { Values }\end{array}$ & $\begin{array}{c}\text { Women's } \\
\text { Health }\end{array}$ & $\begin{array}{c}\text { Genocide- } \\
\text { Holocaust }\end{array}$ & $\begin{array}{c}\text { Pro- } \\
\text { Woman }\end{array}$ & $\begin{array}{c}\text { Rights } \\
\text { Woman/Fetus }\end{array}$ \\
\cline { 2 - 6 } Religious & $50(100 \%)$ & $0(0 \%)$ & $28(51 \%)$ & $4(12 \%)$ & $27(71 \%)$ \\
Medical & $0(0 \%)$ & $40(100 \%)$ & $39(71 \%)$ & $16(47 \%)$ & $15(39 \%)$ \\
Political & $32(64 \%)$ & $5(12 \%)$ & $44(80 \%)$ & $27(79 \%)$ & $29(76 \%)$ \\
Social & $12(24 \%)$ & $15(38 \%)$ & $38(69 \%)$ & $34(100 \%)$ & $22(58 \%)$ \\
$\begin{array}{c}\text { Total Pgs } \\
\text { In Frame }\end{array}$ & $(50)$ & $(40)$ & $(55)$ & $(34)$ & $(38)$ \\
\hline
\end{tabular}

\footnotetext{
${ }^{\mathrm{a}}$ This table sums up the themes uncovered and to what extent each frame depends on particular themes to support the position. The extent of dependence is measured in counted pages (number of pages out of the 217 pages analyzed that contained some or all of the keywords or phrases that indicate a particular subject) and percentages (total number of pages in that theme divided by the total number of pages in that frame).
}

(The Center for Bio-Ethical Reform 2003). This again begs the question, are the rights of adult, human beings, women, superceded by the possible future of the fetus?

The Pro-Woman Frame was primarily supported by the social and political components, but this frame, like the others, was substantially influenced by the remaining themes. In fact, the Rightgrrl (2003) web-pages proclaim that they "welcome the input and participation of Buddhist pro-lifers, atheist pro-lifers or goddess-worshiping prolifers -- provided they identify with the Rightgrrl persona, which includes supporting conservative ideas like free-market economics -- as well as those women who are considered more "typical" in the pro-life camp," maintaining the expectations of a conservative political stance, even if one has alternative beliefs in other components of one's lifestyle.

Table 3 addresses Research Question 3 - how do pro-life social movement groups enlist group members? Table 3 details the rhetorical canon of principles used to focus the 
audience on specific information. Rhetorical devices, such as euphemism, hyperbole, and simile, are used to magnify the importance of certain issues, to diminish the focus on others, and/or invent supports for the pro-life worldview. Hyperbole, the overstatement or exaggeration of particular conditions, is the most used rhetorical device in the repertoire of the pro-life social movement organizations. The Pro-Life Action League encourages the activists to describe abortion as a "holocaust,"...to use "abortuary" or "death camp," to describe the abortion clinic, "abortifacient," for (birth control) pills and IUDs, "fornication," for sex outside marriage, "adultery," for "having an affair" (The ProLife Action League). The fetus is routinely referred to, euphemistically, as a baby or a child, pregnant girls or women are referred to as mothers, and some factions of the prolife movement refer to themselves as "Missionaries to the Unborn" (Missionaries to the Unborn).

While classical rhetoric identifies five canons or established principles and practices, the pro-life movement has primarily focused on the use of only three of these, Invention, Arrangement, and Delivery (Cline 2003). Examples in the following table were drawn from the Pro-Life Action League web-page in order to maintain legitimate comparison. Invention discovers a means of or topic for persuasive arguments. Arrangement selects and assembles the argument, while delivery is the style and manner in which the argument is presented. As Table 3 indicates, the pro-life movement, in this case the social movement organization The Pro-Life Action League, has constructed their argument from the basis that the fetus is a person fully endowed with the rights and obligations equal to or exceeding those of the adult female. 
Table 3: Enlisting Group Members

\begin{tabular}{|c|c|}
\hline $\begin{array}{l}\text { Rhetorical } \\
\text { Canon }\end{array}$ & $\begin{array}{c}\text { Examples of Uses } \\
\text { in Enlisting Group Members }\end{array}$ \\
\hline Invention & $\begin{array}{l}\text { 1) ...pictures of beautiful unborn babies and huge graphic signs of aborted } \\
\text { babies, we line the roads at major intersections, to show Americans the truth } \\
\text { about abortion. } \\
\text { 2) We need you to help show people that abortion is the deliberate taking of an } \\
\text { unborn child's life. } \\
\text { 3) ...choice is seen in the mutilated faces and bodies of the babies murdered by } \\
\text { abortion. }\end{array}$ \\
\hline Arrangement & $\begin{array}{l}\text { 1) The Pro-Life Action League was founded by Joseph M. Scheidler in } 1980 \\
\text { with the aim of saving babies' lives through non-violent direct action. } \\
\text { 2) We use every resource God gives us to save his little children from the } \\
\text { deadly weapons of the abortionists. } \\
\text { 3) Direct action, and even civil disobedience, have an important part to play in } \\
\text { winning the pro-life battle. But violence, we believe, does not. }\end{array}$ \\
\hline Delivery & $\begin{array}{l}\text { 1) Samples of other "inflammatory rhetoric" that pro-lifers must use at } \\
\text { appropriate times to counter pro-abortion jargon are "holocaust," for } \\
\text { America's abortion culture, "abortuary" or "death camp," to describe the } \\
\text { abortion clinic, "abortifacient," for pills and IUDs, "fornication," for sex } \\
\text { outside marriage, "adultery," for "having an affair." } \\
\text { 2) Inflammatory rhetoric must be used with discretion. } \\
\text { 3) A constant litany of inflammatory terms distracts an audience from the main } \\
\text { point of a talk. It may lead them to believe anger and revenge motivate the } \\
\text { speaker. }\end{array}$ \\
\hline
\end{tabular}

The argument is arranged for presentation to allied constituencies through the website, rallies, and workshops, instructing local groups in such packaged strategies as sidewalk counseling, prayer vigils, and sidewalk interventions between women seeking abortions and the clinics. The delivery or style of the arguments suggested by the ProLife Action League includes inflammatory rhetoric, such as holocaust and death camp, used discretely to emphasize and legitimate the ideology of the movement for attracting and sustaining individual and group constituencies.

Finally, research question 4 - how have pro-life organizations used rhetoric for collective mobilization - refers to the framing of the experience of abortion to resonate negatively with constituencies of differing social and political perspectives. See Table 1 
for examples of these differing perspectives. As Table 2 points out, the rhetorical themes used are limited and differ in magnitude of importance according to which constituency is the audience, i.e., the family values frame is supported by religious rhetoric on $100 \%$ of the pages analyzed, but the women's health frame does not use religious rhetoric. Just as any successful advertising campaign depends on a consistent message being repeated over time, so does the Pro-Life Social Movement employ this strategy to encourage collective mobilization. The Family Values constituencies are mobilized around religious values, such as being a missionary to the unborn; Women's Health is focused on women's medical issues, such as Post Abortion Syndrome and links between abortion and breast cancer; Holocaust/Genocide is organized around the political theme comparing abortion to the Nazi Holocaust and racist lynchings; Pro-Woman groups are primarily focused on social issues like "The Women Deserve Better" campaign of the Feminists for Life organization; and Rights - Woman/Fetus is focused on the religious and the political. Repetition of the message and focus on the ideological stance of the audience increase the likelihood of creating collective mobilization. 


\section{CHAPTER V \\ SUMMARY AND CONCLUSIONS}

\section{$\underline{\text { Summary }}$}

The split in the National Right to Life Committee (NRLC) in 1980 created the need for a new rhetoric and strategy in the pro-life social movement. The lobbying strategy employed by the NRLC was deemed a "timid" (Burghardt 1996) means toward the end envisioned by the more radical pro-life advocates, the "passage of a comprehensive "Human Life Amendment" to the Constitution that would outlaw all abortions" (Burghardt 1996). The new strategy required a change in rhetoric to package the abortion issue in a way that would present the pro-life agenda to broader audiences with often varying worldviews. Joseph Scheidler, previously employed as a publicist and considered by many to be the individual most responsible for the creation of the strategies used by the direct-action branch of the pro-life social movement (Burghardt 1996), established the Pro-Life Action League, modeling a national hierarchy and disbursing his direct-action model to various grass-roots, local organizations.

The pro-choice movement, by accepting that the decision of the Supreme Court in Roe v. Wade would be upheld both by the public and the Court, failed to defend the rights granted by the Court's decision in Roe. This defection of the pro-choice movement from advocating for maintaining the spirit of Roe to implementing the rights set out by the Court gave the pro-life social movement complete freedom in interfering 
with access to abortion clinics, influencing the political agenda of the Right, and framing abortion as a religious, social, legal, and woman's problem. The question of personhood of the fetus, as theorized by Kristin Luker (1984), became the primary focus for the prolife argument against abortion. The question of personhood logically led to whether the rights of the fetus supercede the rights of the adult woman, which the pro-life social movement seems to advocate. In order to support such a radical perspective, the pro-life movement required a means "to both align the movement with the larger cultural dictates of society and to mobilize or maintain the support of members" (McCaffrey 2000: 43). The means that they chose was framing the abortion issue differently for differing audiences through the use of rhetoric.

As identified by Cress and Snow (2000), there are three primary tasks necessary for the creation of a successful frame. The first of these tasks is diagnostic framing which "problematizes and focuses attention on an issue, helps shape how the issue is perceived, and identifies who or what is culpable" (Cress and Snow 2000: 1071). This task identifies "the targets or sources of the outcomes sought" (Cress and Snow 2000: 1071). The next task is "prognostic framing (which) stipulates specific remedies or goals for the SMO to work toward and the means or tactics for achieving these objectives" (Cress and Snow 2000: 1071). Finally, if the previous tasks are well-negotiated, the motivational tasks of attracting or retaining membership or collective mobilization of the membership will ensue.

After analyzing 217 pages drawn from the web-sites of fifteen pro-life social movement organizations, four primary rhetorical themes were identified: the religious, 
the medical, the political, and the social. Some or all of these themes were used to support the construction of frames appropriate for presentation to targeted groups.

Through analyzing the rhetoric on the pages selected from the web-sites, five primary frames were identified. Each of the frames was focused on a differing constituency and presented the pro-life agenda in a way constructed to resonate with that particular audience, in order to attract or retain membership from that group or to bring about collective mobilization of the current membership. The rhetoric found to be used most often throughout the web-pages was that of Genocide-Holocaust as measured by pages on which that rhetorical device was used. The Genocide-Holocaust frame used rhetoric from each of the basic themes, religious, medical, political, and social. The second most used rhetoric was that of Family Values. The Family Values frame used each of the primary rhetorical themes, except the medical rhetoric. Women's Health was the next most often used frame. Women's Health used all the primary themes, except religion. The final two frames, Pro-Woman and Rights-Woman/Fetus, were nearly equal in number of pages, 34 pages and 38 pages respectively, and each used all four of the primary themes.

Analysis of the 217 pages of data identified three rhetorical principles or canons used by the pro-life social movement in constructing a coherent program for enlisting and retaining membership. These data were drawn from the Pro-Life Action League website. The rhetorical principles used are invention, arrangement, and delivery. Invention identifies the means or topic for persuasive argument; arrangement assembles the argument; and delivery is the style in which the argument is made. In the case of the ProLife Action League, the topic of the persuasive argument is the personhood of the fetus; 
the arrangement is constructed around the resources used to make the argument; and the delivery is straightforwardly recommended to include inflammatory rhetoric used with discretion, warning that "[a] constant litany of inflammatory terms distracts an audience from the main point of a talk. It may lead them to believe anger and revenge motivate the speaker" (Pro-Life Action League). Collective mobilization depends on presenting the appropriate rhetoric to the targeted group defined by the frame into which the group best fits.

\section{$\underline{\text { Conclusions }}$}

As Scott Applerouth (1999) points out, "despite a group's initial discursive grounding, challengers targeting the state...find it necessary to frame their concerns within a "rational-legal" paradigm" (329) able to be supported by evidence and/or precedence. However, when pro-life activists lowered the level of discourse from the political to the personal, it became necessary to reconstruct the rhetoric and reframe the issues to suit the strategies of the more radical pro-life social movement organizations. This study describes five distinct frames employed by direct-action, pro-life social movement organizations to broaden the resonance of their appeal among groups with differing concerns. The study illustrates the use of rhetoric and rhetorical devices to frame abortion as a social problem, to motivate pro-life action, and to enlist and maintain group membership.

Each frame is focused on a specifically targeted audience and designed to address the concerns or ideology of that particular constituency. There are a limited number of themes, political, social, medical, and religious, used, but each theme contributes support to the tasks necessary for constructing a successful frame. It seems evident that direct- 
action, pro-life social movement organizations have used rhetoric to present their pro-life worldview so that it will attract the broadest, if in some cases seemingly contradictory, audiences.

The frames, i.e., Family Values, Women's Health, Genocide-Holocaust, Pro-Woman, and Rights Woman/Fetus, are constructed to reflect the ideals of targeted audiences, which although they are all pro-life, may have political, religious, or social differences that demand a different spin on the standard rhetoric, such as the rhetoric employed in constructing the Rightgrrl - Rights Woman/Fetus frame and that of the ProLife Action League - Rights Woman/Fetus frame. The Rightgrrl web-page states "we don't believe the rights of the unborn should be subordinated to the rights of women, simply because we've been historically denied the vote" (Rightgrrl 1997-2002). This page constructs the argument for fetal rights using a political, rights-oriented rhetoric; while the Pro-Life Action Leagues constructs the same argument, but bases the discourse on a religious theme, i.e., "[t]he truth is that abortion kills innocent human beings, made in the image and likeness of Almighty God" (Pro-Life Action League 2002). Although each of the organizations is constructing the argument that fetuses have rights that must supercede those of adult women, they use different rhetorical themes in support.

While the themes used to support the construction of the individual frames are few, the arguments made are even more limited. These are that god's plan for women and the family must be adhered to, i.e., Family Values and Genocide-Holocaust frames, and that by adhering to this plan, women, fetuses, and families will be better off, physically, emotionally, and socially, i.e., Women's Health, Pro-Woman, and Rights Woman/Fetus frames. These basic arguments illustrate the pro-life movement's purpose 
of maintaining a conservative family and societal structure. By creating frames that are group specific, the pro-life movement generally does not alienate pro-lifers who may have alternative concerns or ideologies.

According to Benford and Snow (2000: 632), "there have been few systematic studies of the actual contribution of framing processes" to goal attainment in social movements. They also comment that the "further investigation of the relationship between framing processes and the goal attainment efforts of different varieties of movements" (Benford and Snow 2000: 632) would contribute to the literature concerning framing and social movements. This study contributes to the social movement literature by addressing these lacunae of knowledge, by illustrating the use of rhetoric and rhetorical devices in the framing process and describing how this process expands the audiences available to the pro-life message, frames abortion as a social problem, and encourages collective mobilization.

Finally, further investigation of this type of framing for other social movements, such as the pro-choice social movement, would be of importance to the literature and be an interesting comparison to the present study. Any other social movement that is visible on the Internet could be analyzed by this method for framing processes and their contribution to the goal attainment of the social movement organizations involved in the general movement. 


\section{References}

Appelrouth, Scott A. 1999. "Shifting Frames and Rhetorics: A Case Study of the Christian Coalition of New York." The Social Science Journal 36: 329-339.

Benford, Robert and Snow, David. 2000. "Framing Processes and Social Movements: An Overview and Assessment." Annual Review of Sociology 26: 611-639.

Berbrier, Mitch. 1998. "'Half the Battle': Cultural Resonance, Framing Processes, and Ethnic Affectations in Contemporary White Separatist Rhetoric." Social Problems 43: 431-450.

Blanchard, Dallas A. and Terry Prewitt. 1993. Religious Violence and Abortion: The Gideon Project. Gainesville: University Press of Florida.

Brown, Mark T. 2000. "The Morality of Abortion and the Deprivations of Futures." Journal of Medical Ethics 26: 103-107.

Burghardt, Tom. 1995-1996. "Dialectics of Terror - A National Directory of the Direct Action Anti-Abortion Movement and Their Allies." The Bay Area Coalition for Our Reproductive Rights (BACORR).

http://www.webcom.com/ pinknoiz/right/bacorr.html.

Chamberlain, Pam and Jean Hardisty. 2000. "Reproducing Patriarchy: Reproductive Rights Under Siege." The Public Eye Magazine 14 (Summer). http://www.publiceye.org/magazine.

Condit, Celeste. 1990. Decoding Abortion Rhetoric: Communicating Social Change. Urbana and Chicago: University of Illinois Press.

Clarke, Alan. 1987. "Moral Reform and the Anti-Abortion Movement." Sociological Review 35 (1): 123-150.

Cohen, Susan A. 2000. "Abortion Politics and U.S. Population Aid: Coping With a Complex New Law." International Family Planning Perspectives 26: 137-141.

Cline, Andrew R. 2003. Rhetorica: A Rhetoric Handbook. http://rhetorica.net/textbook/canons_of_rhetoric.htm 
Cress, Daniel M. and David A. Snow. 2000. "The Outcome of Homeless Mobilization: The Influence of Organization, Disruption, Political Mediation, and Framing." American Journal of Sociology 105 (4): 1063-1104.

Coalition on Abortion/Breast Cancer. 2003. http://www.abortionbreastcancer.com.

Center for Bio-Ethical Reform. 2003. http://www.cbrinfo.org/about_us.html.

Full Quiver Ministries. 2003. http://www.fullquivermission.com/Main_Page.htm.

Franklin, Charles H. and Lianne C. Kosaki. 1989. "Republican Schoolmaster: The U.S. Supreme Court, Public Opinion, and Abortion." The American Political Science Review 83: 751-773.

Fr. Pavone, Frank. 2001. "Flooding the Internet with Good." Priests for Life. http://priestsforlife.org/columns/floodingtheinternet.html.

Feminists for Life. 2000. http://www.feministsforlife.org.

Ginsburg, Faye. 1989. Contested Lives: The Abortion Debate in an American Community. Berkeley and Los Angeles, California: University of California Press.

Goffman, Erving. 1974. Frame Analysis: An Essay on the Organization of Experience. Cambridge, Massachusetts: Harvard University Press.

Harris, Robert. 2000. "A Handbook of Rhetorical Devices." VirtualSalt. http://www.virtualsalt.com/rhetoric.htm.

Haw, Anne E. and Alane C. Spinney. 1999. "Rhetoric, Repetition, and Violence: A Case Study of Clinic Conflict in Milwaukee." College Literature 26(Winter): 170-193.

Hopkins, Nick and Steve Reicher. 1997. "Social Movement Rhetoric and the Social Psychology of Collective Action: A Case Study of Anti-Abortion Mobilization." Human Relations 50: 261-286.

Hopkins, Nick and Reicher, Steve and Saleem, Jannat. 1996. "Constructing Women's Psychological Health in Anti-Abortion Rhetoric." Sociological Review 44(3): 539-565.

Hopper, Joseph. 1991. "The Rhetoric of Motives in Divorce." Journal of Divorce and Remarriage 14: 33-60.

Horseley, Neal. 2002. http://www.christiangallery.com/atrocity. 
Johnson, Timothy R. and Andrew D. Martin. 1998. "The Public's Conditional Response to Supreme Court Decisions." American Political Science Review 92: 299-309.

Kahane, Leo H. 2000. "Anti-Abortion Activities and the Market for Abortion Services: Protest as a Disincentive." American Journal of Economics and Sociology 59: 463-485.

Life Dynamics. http://www.lifedynamics.com.

Lofland, John and Lynn H. Lofland. 1995. Analyzing Social Settings: A Guide to Qualitative Observation and Analysis, $3^{\text {rd }}$ ed. Belmont, CA: Wadsworth Publishing Co.

Luker, Kristin. 1984. Abortion and the Politics of Motherhood. Berkley: University of California Press.

Mall, David. 1981. "Toward an Understanding of the Abortion Debate: Rhetoric as a Reticulate Structure." In T.W. Hilgers, D.J. Horan, and D. Mall (Eds.), New Perspectives on Human Abortion. Frederick, MD: Aletheia Books, University Publications of America.

McCaffrey, Dawn and Jennifer Keys. 2000. "Competitive Framing Processes in the Abortion Debate: Polarization-Vilification, Frame Saving, and Frame Debunking." Sociological Quarterly 41(Winter): 41-62.

Missionaries to the Unborn. 2003. http://www.mttu.com/main.htm.

Mooney, Christopher Z. 2000. "The Decline of Federalism and the Rise of MoralityPolicy Conflict in the United States." Publius 30; 171-190.

National Abortion and Reproductive Rights Action League. 2003. http://www.naral.org.

National Right to Life Commission. 2003. http://www.nrlc.org.

Operation Save America. 2003. http://www.operationsaveamerica.org/index.html.

Planned Parenthood v. Casey, No. A-655, SUPREME COURT OF THE UNITED STATES, 510 U.S. 1309; 114 S. Ct. 909; 127 L. Ed. 2d 352; 1994 U.S. LEXIS 1325; 62 U.S.L.W. 3520; 94 Daily Journal DAR 2205, February 7, 1994, Decided.

Pro-Life Action League. 2003. http://www.prolifeaction.org.

Rightgrrl. 1997-2002. http://www.rightgrrl.com. 
Roe v. Wade, SUPREME COURT OF THE UNITED STATES, 410 U.S. 959; $93 \mathrm{~S}$. Ct. 1409; 35 L. Ed. 2d 694; 1973 U.S. LEXIS 3282, Feb. 26, 1973.

Solomon, Martha. 1980. "Redemptive Rhetoric: The Continuity Motif in the Rhetoric of Right to Life." Central States Speech Journal 31(1): 52-62.

Staggenborg, Susan. 1991. The Pro-Choice Movement: Organization and Activism in the Abortion Conflict. New York, Oxford: Oxford University Press.

Terkildsen, Mayda and Frauke Schnell. 1997. "How Media Frames More Public Opinion: An analysis of the Women's Movement." Political Research Quarterly 50: 879-900.

Tribe, Laurence H. 1990. Abortion: The Clash of Absolutes. New York: W.W. Norton $\&$ Company.

Webster v. Reproductive Health Services, No. 88-605, SUPREME COURT OF THE UNITED STATES, 492 U.S. 490; 109 S. Ct. 3040; 106 L. Ed. 2d 410; 1989 U.S. LEXIS 3290; 57 U.S.L.W. 5023, April 26, 1989, Argued, July 3, 1989, Decided

Weddington, Sarah. 1992. A Question of Choice. New York: Putnam Publishing Group. 


\section{CURRICULUM VITAE}

NAME: $\quad$ Juanita Raley Shever

ADDRESS: $\quad 314$ Texas Street Apt.2

Denton, Texas 76201

DOB: $\quad$ Lebanon, Kentucky - April 21, 1949

EDUCATION \& $\quad$ B. A., Sociology

TRAINING University of Louisville

1993-1996

PROFESSIONAL SOCIETIES: American Sociological Association

Southwestern Social Sciences Association 